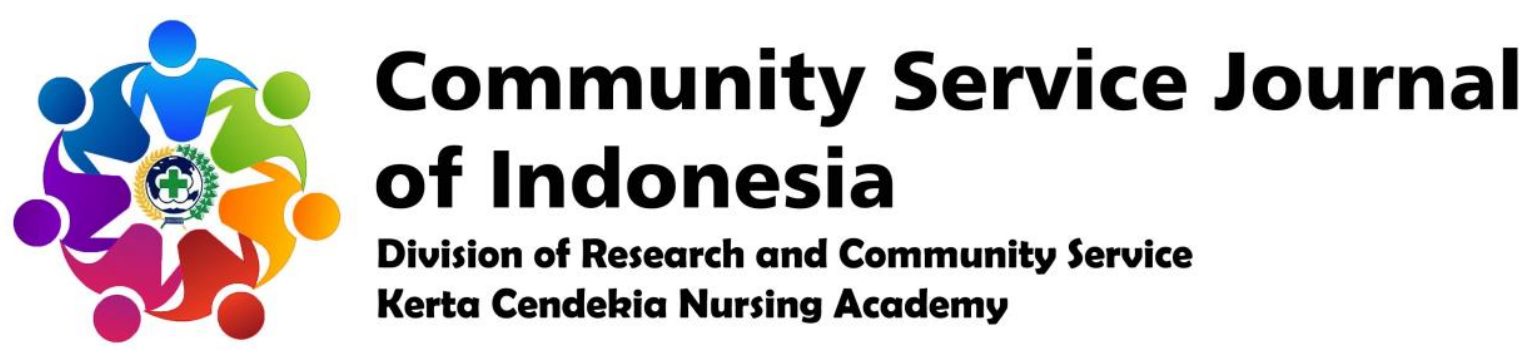

https://ejournal-kertacendekia.id/index.php/csji/index

Community Service Journal of Indonesia 2 (1) (2020): 7-9

Doi: https://doi.org/10.36720/csji.v2i1.142

\title{
INCREASING YOUTH KNOWLEDGE IN HANDLING SYNCOPE CASES IN STUDENTS OF THE SENIOR HIGH SCHOOL OF ANTARTIKA, BUDURAN, SIDOARJO
}

\author{
Marlita Dewi Lestari ${ }^{1}$, Pinik Monika ${ }^{2}$, Elsa Meilani Ekasari ${ }^{2}$, Mirna Paramitha \\ Songupnuan $^{2}$, Fausta Fadir Syair ${ }^{2}$, Sri Wahyuningsih ${ }^{2}$, Indriani Cahya Ningrum ${ }^{2}$
}

\author{
${ }^{1}$ Lecturer of Kerta Cendekia Nursing Academy, Sidoarjo \\ ${ }^{2}$ Students of Kerta Cendekia Nursing Academy, Sidoarjo
}

\begin{abstract}
Health promotion activities about first aid for syncope cases of the Senior High School of Antartika, Buduran, Sidoarjo is one form of community service in the form of counseling aimed at increasing children's knowledge about how first aid in syncope besides fatigue, syncope can also be caused by overheating, being trapped in space closed to lack of oxygen, shocked or surprised. The implementation of these activities on November 20, 2019 took place at the Senior High School of Antartika, Buduran, Sidoarjo. The target is Senior High School students of Antartika, Buduran, Sidoarjo. Before the activity is carried out, there is a process of compiling the activity for approximately 2 weeks before the activity is carried out, starting from determining the theme of counseling to submitting licensing to the parties concerned. As a form of evaluation, the activity was attended by 30 class $\mathrm{X}$ students, participants took part in the activity happily and looked very enthusiastic, health promotion activities could run on time and smoothly.
\end{abstract}

Keywords: Knowledge, syncope cases, first aid health promotion.

(C) 2020 The Authors. Community Service Journal of Indonesia Published by Community Service and Research of Kerta Cendekia Nursing Academy - Kerta Cendekia Nursing Academy

This is an Open Access Article distributed under the terms of the Creative Commons Attribution 4.0 International License which permits unrestricted non-commercial use, distribution, and reproduction in any medium, provided the original work is properly cited.

E-ISSN

2684-7884

\section{INTRODUCTION}

Syncope can be caused by the condition of someone who is tired, overheated, trapped in a confined space to lack of oxygen, shocked. Besides other factors such as lack of blood, lack of sleep, lack of food is also believed to be one of the factors why people faint. One thing that is interesting about people who are unconscious is what's behind it all, in the narrow sense of what is felt by those who are unconscious. My curiosity increases 
when I hear of someone who has been unconscious for days.

\section{OBJECTIVES}

\section{General Purpose}

After counseling, all students of Class $\mathrm{X}$ of the Senior High School of Antartika, Buduran, Sidoarjo are expected to be able to understand the importance of first handling in a syncope condition in a person.

\section{Special Purpose}

After counseling, all representatives of students of Class $\mathrm{X}$ of the Senior High School of Antartika, Buduran, Sidoarjo are expected to be able to:

1. Mention the meaning of syncope condition.

2. Reiterate the cause of syncope.

3. Mention the signs and symptoms of syncope.

4. Mention the first aid to a syncope condition in a person.

\section{PLAN OF ACTION}

Strategy Plan

The strategy plan implemented, including:

1. Coordinate with the principal of the Senior High School of Antartika, Buduran, Sidoarjo to request permission to carry out health education as a nursing program and to help provide useful knowledge for students of the Senior High School of Antartika, Buduran, Sidoarjo.

2. Establish a time contract with students of the Senior High School of Antartika, Buduran, Sidoarjo.

3. Providing health education about how to handle syncope condition in the Senior High School of Antartika, Buduran, Sidoarjo.

\section{Implementation}

Actions taken in the implementation of these activities, including:

1. Contacting the principal of the Senior High School of Antartika, Buduran, Sidoarjo to ask permission to carry out these activities and gather the students of the Senior High School of Antartika, Buduran, Sidoarjo.

2. Prepared the place and media for health promotion.

3. Carried out of the material of handling syncope cases to the all representatives of students of Class $\mathrm{X}$ of the Senior High School of Antartika, Buduran, Sidoarjo.

\section{Setting}

This activity was carried out at the Senior High School of Antartika, Buduran, Sidoarjo.

\section{Target}

Target in this activity is all of the students of Class $\mathrm{X}$ of the Senior High School of Antartika, Buduran, Sidoarjo.

\section{RESULTS AND DISCUSSION}

The activity starts at 12.30 until 13.30 WIB. The activity was carried out at the Senior High School of Antartika, Buduran, Sidoarjo. The counseling time is not according to plan because it adjusts the student schedule after doing the lesson. The students who attended were 30 students. The participants seemed enthusiastic in the process of delivering the material.

Equipment used during the counseling process are laptops, powerpoints, videos, leaflets, LCDs, posters. Using simple language and sentences, students of the Senior High School of Antartika, Buduran, Sidoarjo responded with enthusiasm. The teachers of the Senior High School of 
Antartika, Buduran, Sidoarjo want to work together in implementing this health promotion activity.

Every question asked by participants can be answered by all team members. $90 \%$ of participants can explain the meaning of syncope condition; $90 \%$ of participants can reiterate the cause of syncope; $90 \%$ of participants can mention the sign and symptoms of syncope; and $90 \%$ of participants can mention the first aid of the syncope condition in a person.

\section{CONCLUSION}

Increasing youth knowledge in handling syncope cases in students of the Senior High School of Antartika, Buduran, Sidoarjo was considered quite successful because $90 \%$ of participants can explain the meaning of syncope condition; $90 \%$ of participants can reiterate the cause of syncope; $90 \%$ of participants can mention the sign and symptoms of syncope; and $90 \%$ of participants can mention the first aid of the syncope condition in a person.

\section{REFERENCES}

Ananda, K. S. (2014). 8 Tips Pertolongan pada Orang Pingsan. Retrieved from https://www.merdeka.com/sehat/8-

tips-pertolongan-pertama-pada-orangpingsan.html.

Hidayat, A. A. (2006). Pengantar kebutuhan dasar manusia: Aplikasi konsep dan proses keperawatan. Jakarta: Salemba Medika.

HonestDocs Editorial Team. (2019). 20 Penyebab Pingsan Mendadak yang Harus Diwaspadai. Retrieved from https://www.honestdocs.id/penyebabpingsan.

Ramadhan. (2008). Penangan pingsan. Retrieved from https://forbetterhealth.wordpress. com/2008/12/22/penanganan-pingsan/ Wijayanti, D. P., Putra, K. W. R., Lestyaningsih, A. A., Oktavino, S. M., Mujidah, S., Andayani, A., Tangkelajuk, S. A. T., \& Ayunda, S. (2019). INCREASING YOUTH KNOWLEDGE IN HANDLING SYNCOPE CASES IN STUDENTS OF THE SENIOR HIGH SCHOOL OF MUHAMMADIYAH 3 SIDOARJO, TULANGAN SUBDISTRICT, SIDOARJO DISTRICT. Community Service Journal of Indonesia, 1(1), 8-10. 